\title{
Cutaneous Melanoma Pathologic Primary Tumor TNM Finding v6
}

National Cancer Institute

\section{Source}

National Cancer Institute. Cutaneous Melanoma Pathologic Primary Tumor TNM Finding v6. NCI Thesaurus. Code C48894.

A pathologic finding about one or more characteristics of cutaneous melanoma, following the rules of the TNM AJCC v6 classification system as they pertain to staging of the primary tumor. TNM pathologic primary tumor findings are based on clinical findings supplemented by histopathologic examination of one or more tissue specimens acquired during surgery. 